\title{
Performance of Zoysia matrella 'Zeon' in Shallow Green Roof Substrates under Moisture Deficit Conditions
}

\author{
Nikolaos Ntoulas', Panayiotis A. Nektarios, and Efthimia Nydrioti \\ Laboratory of Floriculture and Landscape Architecture, Department of Crop \\ Science, Agricultural University of Athens, 75, Iera Odos, Athens, 118 55, Greece
}

Additional index words. compost, digital image analysis, green turf cover, Manilagrass, NDVI, relative water content

\begin{abstract}
The use of turfgrasses might provide an additional solution for establishing green roofs in urban environments. The aim of the present study was to determine Manilagrass [Zoysia matrella (L.) Merr. 'Zeon'] drought tolerance when grown under green roof conditions and under two different irrigation regimes. Treatments included: 1) two extensive green roof substrates \{locally produced substrate [3 sandy loam soil:8 pumice: 4 perlite: 4 compost: 1 zeolite (by volume)] and a commercially available substrate based on crushed tiles\}; 2) two substrate depths $(7.5 \mathrm{~cm}$ or $15 \mathrm{~cm})$; and 3) two irrigation regimes ( $3 \mathrm{~mm}$ or $6 \mathrm{~mm}$ of irrigation every 3 days). Substrate characteristics (particle size distribution, saturated and dry bulk density, total porosity, water potential curves, in situ substrate moisture, $\mathrm{pH}$, electrical conductivity, and nutrient analysis), turfgrass growth, and physiological status [green turf cover (GTC), normalized difference vegetation index (NDVI), and leaf relative water content (RWC)] were determined. During moisture deficit periods, GTC, NDVI, and RWC were most affected by substrate depth; moderately affected by irrigation regime; and, to a lesser extent, by substrate type. Turfgrass growth and physiological status were best during moisture deficit conditions in the deeper profile $(15 \mathrm{~cm})$ using the higher amount of irrigation $(6 \mathrm{~mm})$ and the locally mixed substrate.
\end{abstract}

In recent years, green roof construction has been steadily increasing worldwide as a result of the numerous environmental and aesthetic advantages that they provide within the often monotonous and unfriendly landscape of contemporary cities (Claus and Rousseau, 2012). City centers are mostly occupied by older buildings with minimal tolerance of additional weight loads. In such cases, extensive green roofs with shallow substrate depth, reduced weight, and minimal maintenance requirements may be a viable option. However, in the absence of governmental incentives, a financial investment is frequently substantiated from the residents only if green roofs become an accessible and functional space.

Turfgrass growth has seldom been evaluated on extensive green roofs mainly as a result of their water demands, which are higher in comparison with succulents or other xerophytic plants, which conform to the minimal maintenance and natural resources input specified

\footnotetext{
Received for publication 8 Feb. 2013. Accepted for publication 19 May 2013.

We thank Egreen S.A. for donating green roof materials, L. Cambanis S.A. for providing the compost, and LAVA Mining \& Quarrying S.A. for donating pumice.

This article is a portion of a Ph.D. dissertation to be submitted by N. Ntoulas

The mention of a trade mark, proprietary product, or vendor does not imply endorsement by the authors nor does it imply approval to the exclusion of other products that may also be suitable.

${ }^{1}$ To whom reprint requests should be addressed; e-mail ntoulas@aua.gr.
}

by green roof construction guidelines (FLLForschungsgesellschaft Landschaftsentwicklung Landschatsbau. e.v., 2008). Bousselot et al. (2011) evaluated Bouteloua gracilis and Buchloe dactyloides growth in containers with decreasing moisture content. MacIvor and Lundholm (2011) compared survival and cover of different grass species (Festuca rubra, Deschampsia flexuosa, Danthonia spicata) on rooftop modules. In other cases, the studied grasses were mostly ornamentals rather than turfgrass-covered surfaces such as Festuca ovina glauca (Dunnett and Nolan, 2004), Schizachyrium scoparium (Durhman et al., 2006), F. ovina, Trisetum flavescens, Anthoxanthum odoratum (Nagase and Dunnett, 2010), F. scoparia (Dunnett et al., 2008), and Koeleria macrantha (Monterusso et al., 2005; Nagase and Dunnett, 2010).

An increasing number of researchers have indicated that irrigation might be a necessity for establishing extensive green roofs in semiarid regions regardless of the used plants' drought tolerance (Kotsiris et al., 2012b; Ntoulas et al., 2012). Irrigated green roofs are expected to contribute significantly more as compared with non-irrigated ones to the mitigation of the urban heat-island effect through the cooling action of plant transpiration (Spronken-Smith and Oke, 1998; Takebayashi and Moriyama, 2009). Crassulacean acid metabolism (CAM) or xerophytic plants growing under severe water stress are not expected to contribute as much to the cooling of the ambient urban temperature during summer as a result of their minimal transpiration. It has been proposed that irrigation could be applied during the first couple years after establishment or during severe drought conditions to properly establish and sustain the growth of green roof plants (Getter and Rowe, 2006; Latocha and Batorska, 2007; Williams et al., 2010; Wolf and Lundholm, 2008). Considering these irrigation inputs, it would be of interest to investigate the capacity of turfgrass to grow under the limited depth of extensive green roof substrates and to determine their growth response during the Mediterranean summer drought period.

Turfgrasses have the unique ability to serve all of the three requirements of plants that are used in the urban environment, namely aesthetics, function, and recreation (Beard and Green, 1994). Thus, the introduction of turfgrasses on irrigated extensive green roofs would create a usable, functional, and enjoyable urban surface. In an effort to introduce turfgrass species for irrigated extensive green roofs in the semiarid Mediterranean region, several criteria have to be met concerning species selection, substrate type, and substrate depth.

The effects of extensive green roof substrate type and depth on sustainability of both succulent and native plant species in different climatic regions have been extensively researched (Boivin et al., 2001; Dunnett et al., 2008; Durhman et al., 2007; Nektarios et al., 2011a). Substrates have been formulated from materials that are lightweight, maintain adequate moisture for plant growth, facilitate the removal of excess water, provide nutrients, and possess an appropriate $\mathrm{pH}$ and salinity for plant growth (FLL-Forschungsgesellschaft Landschaftsentwicklung Landschatsbau. e.v., 2008; Getter and Rowe, 2006). Inorganic materials such as crushed tiles, calcined clay, zeolites, sand, heat-expanded shale (Beattie and Berghage, 2004; Thuring et al., 2010), pumice, and lava (Kotsiris et al., 2012b; Nektarios et al., 2011a; Rowe et al., 2006) have been customarily used on green roofs. Organic substances such as peat and composts have also been used but at smaller participation percentages to prevent substrate subsidizing as a result of decomposition (Williams et al., 2010).

As substrate depth decreases, plant growth and survival are reduced and fewer plant species are able to adapt and survive (Boivin et al., 2001; Dunnett and Nolan, 2004; Dunnett et al., 2008; Durhman et al., 2007; Getter and Rowe, 2008; VanWoert et al., 2005). The substrate depths that have been tested for extensive green roofs have varied from $2.5 \mathrm{~cm}$ to $15 \mathrm{~cm}$. The difficulty of growing plants in extremely shallow substrates is mainly attributed to the ease of substrate moisture depletion and to the increased substrate temperature extremes (Boivin et al., 2001). However, it has been reported that irrigation has the capacity to compensate for a reduced substrate depth in extensive green roof types. VanWoert et al. (2005) found that plant sustainability and growth were improved when irrigation was applied and that irrigation could counteract the difficulties imposed by the reduced substrate depth.

The first objective of this research was to compare the growth of Manilagrass [Zoysia 
matrella (L.) Merr. 'Zeon'] in two different substrates. The second objective was to investigate the impact of increasing either substrate depth or the amount of irrigation on Manilagrass growth and recovery potential during and after moisture deficit periods, respectively.

\section{Materials and Methods}

\section{Experimental design and setup}

A 2-year outdoor study was conducted on a rooftop at the Laboratory of Floriculture and Landscape Architecture, Agricultural University of Athens, Athens, Greece (lat. $37^{\circ} 59^{\prime} \mathrm{N}$, long. $23^{\circ} 42^{\prime}$ E, $35 \mathrm{~m}$ a.s.1.) from 19 Aug. 2009 until 14 Oct. 2011. The study comprised 40 plots of $0.81 \mathrm{~m}^{2}$ each $(0.9 \mathrm{~m} \times 0.9$-m internal dimensions). Experimental arrangement was multifactorial with three factors: two substrate types, two substrate depths, and two irrigation regimes replicated five times.

The experimental plots were constructed on a building roof, which was covered with the following consecutive layers: 1) vapor barrier (Eshaelastic; Alfa Alfa Energy SA, Attika, Greece); 2) 20-mm polystyrene thermal insulation with aluminium foil at one side (Tempra; Vaportherm, Alfa Alfa Energy SA); 3) paintable primer to enable appropriate contact of waterproofing asphalt panes onto thermal insulation (Extralac; Alfa Alfa Energy SA); and 4) two layers of waterproofing asphalt panes (Eshagum Antiroot B2; Alfa Alfa Energy SA) with a weight of $4 \mathrm{~kg} \cdot \mathrm{m}^{-2}$ including a root-repellent substance (Preventol).

On top of the asphalt panes, wooden boards $2 \mathrm{~cm}$ thick with variable height were used to create adjacent plots and prevent mechanical and hydrological continuity between the plots and the surrounding area. Within each experimental plot, the asphalt panes were covered with a protection mat, which was a synthetic cloth made of nonrotting synthetic polyester fibers having $5 \mathrm{~mm}$ thickness and a dry weight of $0.47 \mathrm{~kg} \cdot \mathrm{m}^{-2}$ that also acts as a water reservoir by retaining $5 \mathrm{~L} \cdot \mathrm{m}^{-2}$ of water according to the manufacturer claims (SSM 45; Zinco, Egreen, Athens, Greece). A drainage layer made of recycled polyethylene with $25 \mathrm{~mm}$ height and a weight of $1.7 \mathrm{~kg} \cdot \mathrm{m}^{-2}$ (FD25; Zinco, Egreen) with waterretaining troughs and openings for ventilation was placed over the protection cloth. The drainage layer had the capacity to store $3 \mathrm{~L} \cdot \mathrm{m}^{-2}$ serving as additional water storage. Within each plot, the drainage layer was covered by a non-woven geotextile (SF; Zinco, Egreen) made of thermally strengthened polypropylene, having $600 \mu \mathrm{m}$ thickness, a mass of $0.1 \mathrm{~kg} \cdot \mathrm{m}^{-2}$, apparent opening size of $D_{90}=95 \mu \mathrm{m}$, and water flow rate of $0.07 \mathrm{~m} \cdot \mathrm{s}^{-1}$. The filter sheet was used to prevent fine particle migration from the substrate toward the drainage layer to ensure that it would not clog and would function effectively. The geotextile was stapled to the side boards of each experimental plot and cut below the final substrate surface to interrupt the continuation of geotextile toward the ambient environment and thus minimize any potential wick-like capillary water movement toward the atmosphere.
The experimental plots were randomly filled with two substrates. The first one $\left(\mathrm{S}_{15}:\right.$ Pum $_{40}:$ Per $\left._{20}: \mathrm{C}_{20}: \mathrm{Z}_{5}\right)$ comprised sandy loam soil (S), pumice (Pum), perlite (Per), compost $(\mathrm{C})$, and clinoptilolite zeolite $(\mathrm{Z})$ at the following volumetric proportions: 3 sandy loam soil: 8 pumice: 4 perlite: 4 compost: 1 zeolite. The materials were mixed uniformly. The sandy loam soil had $77.0 \%$ sand, $7.8 \%$ silt, $15.2 \%$ clay and $0.703 \%$ (w/w) organic matter, a $\mathrm{pH}$ of 8.63 , and an electrical conductivity (EC) of $80 \mu \mathrm{S} \cdot \mathrm{cm}^{-1}$. Pumice had a granulometry of 0.05 to $8 \mathrm{~mm}$ (LAVA; Mineral \& Quarry A.D., Athens, Greece). Zeolite was a clinoptilolite with a granulometry of 0.8 to $2.5 \mathrm{~mm}$ (S \& B Industrial Minerals A.D., Athens, Greece) and perlite (Perloflor; ISOCON A.D., Athens, Greece) had a particle distribution of 0.25 to $5 \mathrm{~mm}$. The compost comprised straw, sawdust, yard waste (clippings and wood chips), and dairy cow, horse, and chicken manure. The second substrate was commercially available (Zinco, Egreen) based on crushed tiles (the exact composition and proportions falls under company proprietary restrictions).

Half the plots were randomly assigned to each of the two substrate depths (either $7.5 \mathrm{~cm}$ or $15 \mathrm{~cm}$ ). Plots were then filled to their respective depths $(7.5$ and $15 \mathrm{~cm})$ with the two substrate mixtures. After substrates were placed into the plots, light compression and leveling were applied.

\section{Substrate measurements}

The substrate granulometry was determined using a series of sieves of various sizes (ASTM D 2974-07a, 2007) that vibrated on a mechanical shaker (Vibratory Sieve Shaker AS 200 basic; Retsch Ltd., Haan, Germany). The particle distribution of each material was plotted on a logarithmic scale to investigate their compliance with the corresponding FLL-Forschungsgesellschaft Landschaftsentwicklung Landschatsbau. e.v. (2008) specifications.

Water potential curves of the substrates were determined according to Nektarios et al. (2011b) using a 100-cm column comprised of 20 rings, each $5 \mathrm{~cm}$ in height. Total porosity and dry and saturated bulk density of each substrate were determined using lysimeters $15 \mathrm{~cm}$ in height with a $30.5 \mathrm{~cm}$ inner diameter (Nektarios et al., 2011a). The pH and EC of the substrates were determined using a 1:5 $(\mathrm{w} / \mathrm{w})$ substrate-to-water extraction.

\section{Turfgrass establishment and maintenance}

Manilagrass was established by plugging on 19 Aug. 2009, 1 year before the initiation of moisture deficit study to achieve adequate and uniform growth between plots. Plugs having dimensions of $5 \mathrm{~cm} \times 5 \mathrm{~cm}$ were prepared from washed sod. At each experimental plot, 20 plugs were planted in a gridlike pattern with a spacing of $15 \times 15 \mathrm{~cm}$ between the plugs. Zoysia matrella 'Zeon' was selected as the turfgrass species because it exhibits several desirable characteristics such as: 1) increased tolerance to extended periods of moisture deficit and shade in comparison with other cultivars (Morris, 2001; Qian and Engelke, 1997); 2) lateral (creeping) growth habit with limited vertical growth that require minimal mowing (Volterrani et al., 2008); 3) natural prevention of weed encroachment as a result of vigorous root, stolon, and rhizome production that creates a compact and thick mat (De Luca et al., 2008a); 4) cold tolerance that permits earlier green up in spring and longer retention of fall color (De Luca et al., 2008b; Patton and Reicher, 2007); and 5) tolerance to insect and disease problems (Anderson et al., 2007; Patton, 2010).

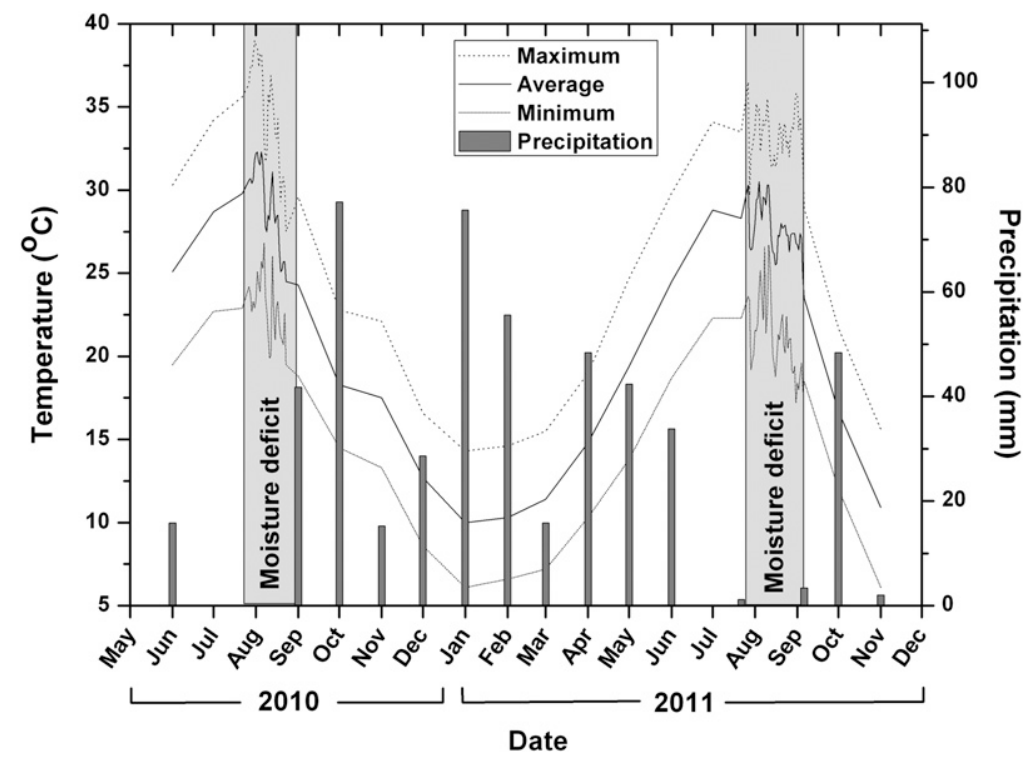

Fig. 1. Monthly precipitation and maximum, minimum and average air temperature for the 2 study years (2010 and 2011). The gray areas correspond to the two moisture deficit periods in which daily maximum, minimum, and average air temperature are presented. 
During the establishment period (19 Aug. 2009 until 1 July 2010), plots were irrigated according to seasonal demands. More specifically from 19 Aug. to 15 Oct. 2009, plots were irrigated once a day to promote Manilagrass establishment and prevent moisture stress. Irrigation initiated again after dormancy termination (20 Mar. 2010) and was applied every other day until the initiation of moisture deficit treatments.

Plots were left unmowed during 2009 as a result of the very limited upward growth of Manilagrass sward. In 2010 and 2011, plots were mowed to a height of $60 \mathrm{~mm}$ in biweekly intervals from June until the initiation of moisture deficit periods. Water-soluble granular fertilizer (Complesal 12-12-17 with a nitrogen content of $6.5 \%$ as $\mathrm{NH}_{4}{ }^{+}$and $5.5 \%$ as $\mathrm{NO}_{3}, 12 \mathrm{~N}-5.2 \mathrm{P}-14.1 \mathrm{~K}-1.2 \mathrm{Mg}-8.0 \mathrm{~S}$; Agrevo Hellas S.A., Athens, Greece) was applied at a rate of $25 \mathrm{~g} \cdot \mathrm{m}^{-2}$ during Manilagrass establishment on 21 May, 25 June, and 18 July 2010.

\section{Water inputs during moisture deficit periods and recovery}

Moisture deficit treatments were repeated in time (years 2010 and 2011). In 2010, moisture deficit period initiated on 10 Aug. and ended on 7 Sept., whereas in 2011, it initiated on 10 Aug. and ended on 20 Sept. Termination of each moisture deficit period coincided with the first fall rainfall for both study years.

Moisture deficit periods. Before the initiation of each stress period, all plots were irrigated to saturation to produce uniform wet conditions. From then on, irrigation was applied every $3 \mathrm{~d}$ at a rate of $3 \mathrm{~mm}$ for the low irrigation regime and $6 \mathrm{~mm}$ for the high irrigation regime. Based on 10-year data of the Laboratory of General and Agricultural Meteorology of the Agricultural University of Athens, the average actual evapotranspiration for the months of July and August is $5 \mathrm{~mm} \cdot \mathrm{d}^{-1}$ (Kotsiris et al., 2012a). Thus, the applied irrigation regimes of $6 \mathrm{~mm}$ and $3 \mathrm{~mm}$ applied in 3-d intervals corresponded to $40 \%$ and $20 \%$ of actual evapotranspiration, respectively. Plots were hand-irrigated with a hose equipped with a Wohnungswasserzähler Typ ETR flow meter having a delivery accuracy of $0.1 \mathrm{~L}$ (Rossweiner Armaturen \& Messgeräte $\mathrm{GmbH}$ \& Co. oHG, Rosswein, Germany).

Recovery periods. In fall of both study years, plots were left without irrigation to investigate their recovery based on natural rainfall events. After winter, irrigation was applied daily in Spring 2011 until the initiation of the moisture deficit period to promote Manilagrass growth and to reach uniform turfgrass cover among treatments.

\section{Measurements}

Volumetric substrate moisture content was determined every $3 \mathrm{~d}$ before irrigation with the use of a WET-2 sensor that measured a cylindrical sampling area of $65 \mathrm{~mm}$ in depth $\times$ $45 \mathrm{~mm}$ in width (Delta-T Devices, Cambridge, U.K.) connected to a $\mathrm{HH} 2$ handheld moisture meter (Delta-T Devices) calibrated using the
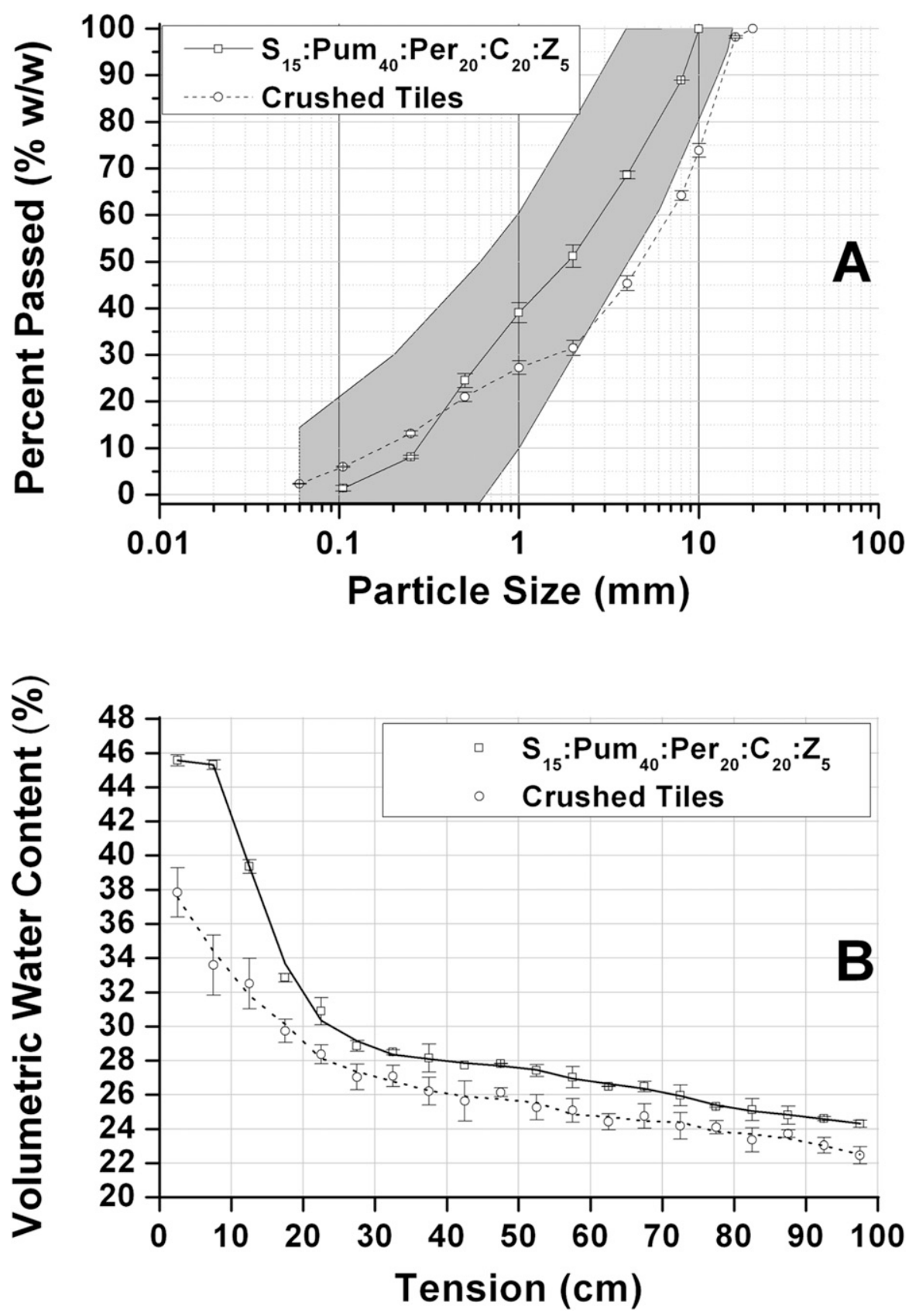

Fig. 2. (A) Particle size distribution of the two substrates $\left(\mathrm{S}_{15}: \operatorname{Pum}_{40}: \operatorname{Per}_{20}: \mathrm{C}_{20}: Z_{5}\right.$, where $\mathrm{S}=$ sandy loam soil; Pum = pumice; $\mathrm{Per}=$ perlite; $\mathrm{C}=$ compost; and $\mathrm{Z}=$ zeolite in volumetric proportions that are indicated by their subscripts and commercial based on crushed tiles). The gray area represents the specified particle size range by FLL-Forschungsgesellschaft Landschaftsentwicklung Landschatsbau. e.v. (2008) guidelines. (B) Water potential curve for each substrate. Values are the mean of three replications $( \pm \mathrm{SE})$.

substrate-specific methodology of Kargas et al. (2013).

Percentage of GTC was determined using digital images of each plot taken on each irrigation date with a Canon IXUS 100 IS digital camera mounted on the top of a sealed box $(0.7 \mathrm{~m} \times 0.7 \mathrm{~m} \times 1 \mathrm{~m}$ in height $)$, which was constructed to secure consistent lighting conditions throughout the image-acquisition procedure. The box was equipped with four fluorescent lamps of 1200 lumens each, which were mounted on the upper, inner side of the box. Camera settings were maintained constant during the study comprising an aperture of F3.2, white balance set to fluorescent, ISO sensitivity set to 200 , and focal length of $33 \mathrm{~mm}$. The images were in JPEG format with a size of $1600 \times 1200$ pixels. Each image was cropped using Adobe PhotoShop CS3 software (Adobe Systems Inc., CA) to remove any unwanted image portion. Green Turf Cover percentage was determined using digital image analysis SigmaScan Pro Version 5.0 software (SigmaScan Pro; Systat Software Inc., Chicago, IL) (Bousselot et al., 2010; Karcher and Richardson, 2005; Olmstead et al., 2004; Richardson et al., 2001). Green leaves were selectively identified in the 
images by setting the hue range from 47 to 107 and saturation from 0 to 100 . In each image, GTC percentage was determined by dividing the number of green pixels with the total pixel count of each image.

Spectral reflectance was determined before irrigation between 1200 and 1400 HR using two double-channel SKR 1800 sensors (Skye Instruments Ltd., Powys, U.K.). Sensors had center wavelengths of $650 \mathrm{~nm}$ (red) and $800 \mathrm{~nm}$ [near infrared (NIR)] and a bandwidth of $\approx$ $10 \mathrm{~nm}$. The sensors were connected to a display meter (SKL 925 SpectroSense2+.GPS; Skye Instruments Ltd.) and mounted on a telescopic hand-held pole (SKL 910; Skye Instruments Ltd.) with the downward-facing sensor $1.30 \mathrm{~m}$ above the turf surface, giving a sampling area of $0.25 \mathrm{~m}^{-2}$. Red and NIR reflectances were used to calculate NDVI values.

Leaf RWC of Manilagrass was measured as described by Turner (1981). A 1.5-g leaf sample was collected from fully expanded leaves in each plot every $3 \mathrm{~d}$, before irrigation between 1200 and $1400 \mathrm{HR}$. Leaves were immersed in deionized water for $24 \mathrm{~h}$, and the turgid weight of each sample was determined. Subsequently, the leaves were ovendried for $48 \mathrm{~h}$ at $75^{\circ} \mathrm{C}$, and their dry weight was determined. The RWC was calculated based on the following formula:

$$
R W C=\frac{(F W-D W)}{(T W-D W)} \times 100
$$

where $F W=$ fresh weight, $D W=$ dry weight, and $T W=$ turgid weight of the leaf tissue. RWC measurements ended whenever Manilagrass turned dormant and leaves' green color was lost.

Meteorological data. Throughout the duration of the research, air temperature and precipitation were monitored by the weather station of the Laboratory of General and Agricultural Meteorology of the Agricultural University of Athens, Athens, Greece, located $15 \mathrm{~m}$ away from the experimental site (Fig. 1).

Statistical analyses. Data were subjected to statistical analysis using JMP Version 8 statistical software (SAS Institute Inc., Cary, NC) following multivariate analysis of variance (MANOVA). As a result of statistical treatment differences between years, data were presented separately for each year. However, similar trends were observed in the data as discussed subsequently. The main research interest was focused on treatment effects for turf growth and quality factors (GTC, NDVI), RWC, and substrate moisture at each separate sampling date. MANOVA was performed to compare treatment effects within each sampling date as a three-way factorial design (substrate type $\times$ substrate depth $\times$ irrigation regime). Means were separated using Fisher's protected least significant difference at a $0.05 P$ level $(P<0.05)$.

\section{Results and Discussion}

Substrate characteristics. Particle size distribution differed between the two substrates. Only the substrate formulated by locally available materials was within the particle size distribution guidelines suggested by FLLForschungsgesellschaft Landschaftsentwicklung Landschatsbau. e.v. (2008) for extensive green roof construction. The crushed tiles substrate slightly deviated from the guidelines because it was coarser for all particles sizes exceeding $2 \mathrm{~mm}$ in diameter (Fig. 2A).

The substrate that was formulated by locally available materials exhibited higher water retention capacity for all tensions (Fig. 2B). Its increased water capacity was attributed to the finer texture and to the creation of greater porosity within the substrate that favored the retention of water at low tensions.

Saturated and dry bulk density was less in the substrate formulated by locally available materials $(8.2 \%$ at saturation and $19.3 \%$ when dry) compared with the crushed tiles substrate as a result of the lightweight nature of its constituents. By contrast, total porosity of substrate formulated by locally available materials was higher by $6.5 \%$ compared with the crushed tiles substrate (Table 1).

Apart from the physical differences, substrates significantly differed concerning their chemical characteristics as well. The substrate with crushed tiles had an organic content that was 2.8 times greater compared with the substrate composed of locally available materials (Table 1 ). The increased organic matter of the crushed tiles substrate resulted in higher total nitrogen, potassium, magnesium, and sodium compared with locally formulated substrate. Calcium was also significantly higher in the crushed tiles substrate presumably as a result of the excess of calcium contained in the crushed tiles. In contrast, phosphorus was the only element that was found in similar amounts in both substrates. The $\mathrm{pH}$ and EC of both substrates were similar and within the optimum levels for green roofs (FLL-Forschungsgesellschaft Landschaftsentwicklung Landschatsbau. e.v., 2008; Table 1).

Moisture deficit periods. When all data were pooled over each study year, it was obvious that substrate depth was the most significant factor with deeper substrates providing larger values for GTC, substrate moisture content, NDVI, and RWC compared with shallow ones (Table 2). Similar results have been reported by several researchers for various plants species growing in different green roof substrate depths. In most cases, deeper substrates favored plant growth and survival and increased the number of plant species capable of providing sustainable growth on green roof systems. Nektarios et al. (2011a) found higher growth index of the native Dianthus fruticosus ssp. fruticosus, growing in $15-\mathrm{cm}$ rather than $7.5-\mathrm{cm}$ depth, whereas Dunnett et al. (2008) reported that productivity, species richness, and diversity of 15 herbaceous perennial grass and herb species were higher when a substrate depth of $20 \mathrm{~cm}$ was used compared with a depth of $10 \mathrm{~cm}$. Similarly for 12 Sedum species Getter and Rowe (2008) found increased growth and coverage at $10 \mathrm{~cm}$ and $7 \mathrm{~cm}$ compared with 4-cm substrate depth. Benvenuti and Bacci (2010) reported a significantly greater vegetation cover and growth of 20 species originated from dry habitats produced when substrate depth increased from $10 \mathrm{~cm}$ to $15 \mathrm{~cm}$.

Irrigation regime was also significant but to a lesser degree compared with substrate depth. The higher irrigation regime of $6 \mathrm{~mm}$ increased GTC only in 2011, whereas NDVI and RWC increased in both study years. In contrast, substrate type was indifferent for GTC, NDVI, and RWC Manilagrass values, although moisture content of locally formulated substrate exhibited increased moisture retention capacity (Table 2 ).

In situ substrate moisture content. During the moisture deficit periods (10 Aug. until 7 Sept. 2010 and 10 Aug. until 20 Sept. 2011), substrate moisture quickly declined during the first $10 \mathrm{~d}$ for all treatments (Fig. 3). Differences between moisture content were evident for all treatments but the most pronounced ones occurred between the two substrate depths. The substrate formulated by locally available materials retained higher moisture compared with the crushed tiles substrate in both study years except from the five last sampling dates of 2010 (Fig. 3). These results were expected as a result of the observed differences in water potential curves between the two substrates (Fig. 2B), where locally formulated substrate retained higher moisture content compared with the crushed tiles one.

Substrate depth was the most influential factor because it provided the largest differences for all measurements compared with

Table 1. Nutrient analysis, chemical and physical properties of substrate $\mathrm{S}_{15}: \operatorname{Pum}_{40}: \operatorname{Per}_{20}: \mathrm{C}_{20}: Z_{5}(\mathrm{~S}=$ sandy loam soil; Pum = pumice; $P$ er = perlite; $C=$ compost $Z=$ zeolite in volumetric proportions that are indicated by their subscripts) and commercial substrate based on crushed tiles. ${ }^{z}$

\begin{tabular}{lccc}
\hline & $\mathrm{S}_{15}:$ Pum $_{40}: \mathrm{Per}_{20}: \mathrm{C}_{20}: \mathrm{Z}_{5}$ & Crushed tiles & Method of analysis \\
\hline Organic matter $(\%)$ & $2.78 \pm 0.18$ & $7.71 \pm 0.33$ & Loss on ignition \\
Total N $(\%)$ & $0.180 \pm 0.02$ & $0.46 \pm 0.04$ & Kjeldahl method \\
Extractable P $\left(\mathrm{mg} \cdot \mathrm{kg}^{-1}\right)$ & $107.8 \pm 3.8$ & $113.7 \pm 3.0$ & Colorimetrically \\
Exchangeable $\mathrm{K}\left(\mathrm{mg} \cdot \mathrm{kg}^{-1}\right)$ & $1,919 \pm 28.2$ & $1,303 \pm 24.5$ & Atomic absorption \\
Exchangeable $\mathrm{Mg}\left(\mathrm{mg} \cdot \mathrm{kg}^{-1}\right)$ & $415 \pm 5.6$ & $788 \pm 7.3$ & spectrophotometry \\
Exchangeable Ca $\left(\mathrm{mg} \cdot \mathrm{kg}^{-1}\right)$ & $1,510 \pm 12.3$ & $3,928 \pm 28.2$ & $(\mathrm{GBC} 932 \mathrm{~A} / \mathrm{A})$ \\
Exchangeable Na $\left(\mathrm{mg} \cdot \mathrm{kg}^{-1}\right)$ & $487 \pm 3.2$ & $633 \pm 5.1$ & \\
pH & $7.86 \pm 0.006$ & $7.55 \pm 0.006$ & $1: 5(\mathrm{w} / \mathrm{w})$ extraction \\
Electrical conductivity $\left(\mu \mathrm{S} \cdot \mathrm{cm}^{-1}\right)$ & $908.60 \pm 5.49$ & $877.3 \pm 25.12$ & $1: 5(\mathrm{w} / \mathrm{w})$ extraction \\
Saturated bulk density $\left(\mathrm{kg} \cdot \mathrm{L}^{-1}\right)$ & $1.320 \pm 0.02$ & $1.438 \pm 0.03$ & Lysimeter \\
Dry bulk density $\left(\mathrm{kg} \cdot \mathrm{L}^{-1}\right)$ & $0.824 \pm 0.006$ & $1.021 \pm 0.004$ & Lysimeter \\
Total porosity $(\%)$ & $45.9 \pm 0.7$ & $43.1 \pm 1.1$ & Lysimeter \\
\hline
\end{tabular}

${ }^{z}$ Values are the mean of three replications ( $\left.\pm \mathrm{SE}\right)$.

$\mathrm{N}=$ nitrogen; $\mathrm{P}=$ phosphorus $; \mathrm{K}=$ potassium $; \mathrm{Mg}=$ magnesium $; \mathrm{Ca}=$ calcium; $\mathrm{Na}=$ sodium . 


\begin{tabular}{|c|c|c|c|c|c|c|c|c|}
\hline \multirow[b]{4}{*}{ Treatment } & \multicolumn{8}{|c|}{ Moisture deficit period } \\
\hline & \multirow{2}{*}{\multicolumn{2}{|c|}{$\begin{array}{l}\begin{array}{l}\text { Substrate } \\
\text { moisture }\end{array} \\
-----\% \mathrm{v} / \mathrm{v}-----\end{array}$}} & \multirow{2}{*}{\multicolumn{2}{|c|}{$\begin{array}{c}\text { Green } \\
\text { turf cover } \\
--\%\end{array}$}} & \multicolumn{2}{|c|}{ NVDI } & \multicolumn{2}{|c|}{$\begin{array}{l}\text { Leaf relative } \\
\text { water content }\end{array}$} \\
\hline & & & & & --------- & ------- & -------- & $\begin{array}{ll}------ \\
\end{array}$ \\
\hline & 2010 & 2011 & 2010 & 2011 & 2010 & 2011 & 2010 & 2011 \\
\hline \multicolumn{9}{|l|}{ Substrate (S) } \\
\hline $\mathrm{S}_{15}:$ Pum $_{40}: \operatorname{Per}_{20}: \mathrm{C}_{20}: \mathrm{Z}_{5}^{\mathrm{y}}$ & 12.18 & 11.72 & 42.86 & 33.79 & 0.6284 & 0.6316 & 62.25 & 66.93 \\
\hline Crushed tile & 9.59 & 8.42 & 41.49 & 33.39 & 0.6132 & 0.6299 & 59.89 & 66.40 \\
\hline Significance & $* \mathrm{x}$ & $* * *$ & $\mathrm{NS}^{\mathrm{w}}$ & NS & NS & NS & NS & NS \\
\hline \multicolumn{9}{|l|}{ Depth (D) } \\
\hline Shallow $(7.5 \mathrm{~cm})$ & 10.09 & 9.07 & 35.17 & 28.81 & 0.5737 & 0.5856 & 56.20 & 62.60 \\
\hline Deep $(15 \mathrm{~cm})$ & 11.68 & 11.07 & 49.17 & 38.37 & 0.6679 & 0.6760 & 65.94 & 70.64 \\
\hline Significance & NS & $*$ & $* * *$ & $* *$ & $* * *$ & $* * *$ & $*$ & $*$ \\
\hline \multicolumn{9}{|l|}{ Irrigation (I) } \\
\hline $3 \mathrm{~mm}$ & 10.20 & 10.87 & 39.08 & 29.86 & 0.5980 & 0.5820 & 56.94 & 61.68 \\
\hline $6 \mathrm{~mm}$ & 11.57 & 9.28 & 45.27 & 37.32 & 0.6436 & 0.6795 & 65.20 & 71.56 \\
\hline Significance & NS & NS & NS & $*$ & $*$ & $* * *$ & $*$ & $*$ \\
\hline LSD & 2.132 & 1.660 & 8.489 & 7.097 & 0.0409 & 0.0292 & 7.90 & 7.54 \\
\hline \multicolumn{9}{|l|}{ Interactions } \\
\hline $\mathrm{S} \times \mathrm{D}$ & NS & NS & NS & NS & NS & NS & NS & NS \\
\hline $\mathrm{S} \times \mathrm{I}$ & NS & NS & NS & NS & NS & NS & NS & NS \\
\hline $\mathrm{D} \times \mathrm{I}$ & NS & NS & NS & NS & NS & NS & NS & NS \\
\hline $\mathrm{S} \times \mathrm{D} \times \mathrm{I}$ & NS & NS & NS & NS & NS & NS & NS & NS \\
\hline
\end{tabular}

${ }^{\mathrm{z}}$ Means derive from pooled data over each moisture deficit period of either 2010 or 2011.

${ }^{\mathrm{y}} \mathrm{S}=$ sandy loam soil; Pum = pumice; $\mathrm{Per}=$ perlite; $\mathrm{C}=$ compost; $\mathrm{Z}=$ zeolite in volumetric proportions that are indicated by their subscripts.

x*,**,*** Significant at $P<0.05,0.01$, and 0.001 , respectively.

${ }_{\mathrm{w}}^{\mathrm{NS}}=$ nonsignificant at $P<0.05$.

$\mathrm{NDVI}=$ normalized difference vegetation index.

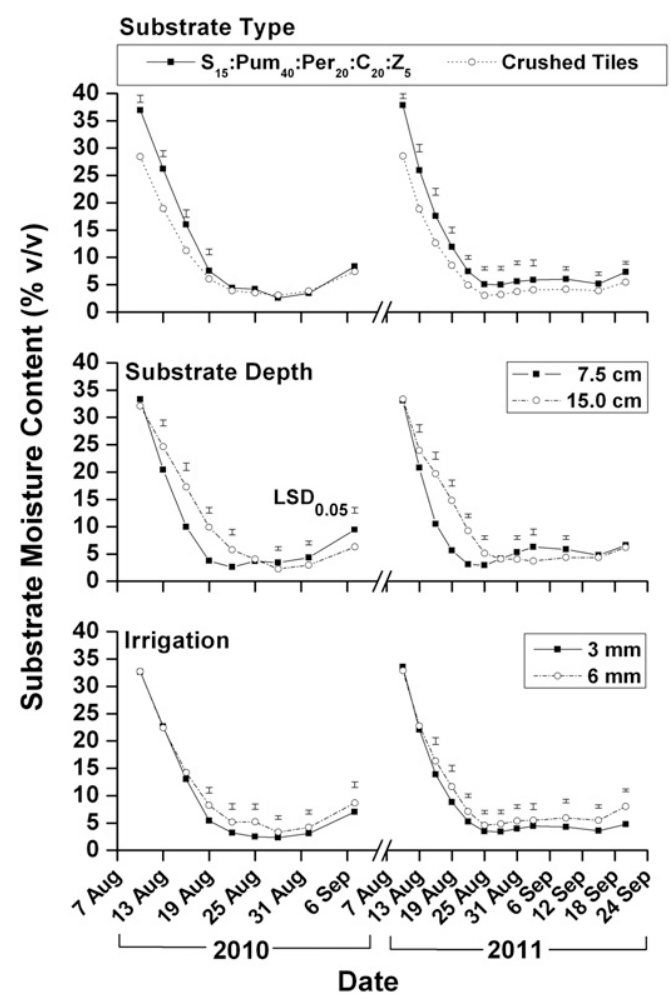

Fig. 3. Substrate moisture content $(\% \mathrm{v} / \mathrm{v})$ as affected by substrate type $\left(\mathrm{S}_{15}: \mathrm{Pum}_{40}: \operatorname{Per}_{20}: \mathrm{C}_{20}: \mathrm{Z}_{5}\right.$, where $\mathrm{S}=$ sandy loam soil; Pum = pumice; $\mathrm{Per}=$ perlite $\mathrm{C}=$ compost; and $\mathrm{Z}=$ zeolite in volumetric proportions that are indicated by their subscripts and commercial based on crushed tiles), substrate depth (7.5 or 15 $\mathrm{cm}$ ), and irrigation regime $(3 \mathrm{~mm}$ or $6 \mathrm{~mm}$ ) during the moisture deficit periods. Values are the mean of five replications. Bars represents Fisher' least significance difference (LSD) at $P<0.05$.

substrate type and irrigation regime in both study years (Table 2). The deeper green roof profiles $(15 \mathrm{~cm})$ exhibited higher moisture content during the first six sampling dates
(Fig. 3). However, this situation was reversed after the sixth and seventh sampling dates for 2010 and 2011, respectively, because the moisture content at shallow depth $(7.5 \mathrm{~cm})$ reached higher values compared with $15-\mathrm{cm}$ depth substrates. This pattern occurred in both study years and has also been observed in other similar green roof studies (Ntoulas et al., 2012). The higher moisture content in the shallow substrates was caused by the earlier induction into dormancy of the turfgrass growing in shallow depth compared with the deeper substrates as substantiated by GTC and NDVI measurements (Figs. 4 and 5). The earlier induction into dormancy reduced turf sward transpiration in shallow substrates and resulted in substrate moisture content increase. In contrast, plants growing in deeper substrates were still transpiring and thus depriving the substrate from its moisture. Irrigation regime also affected substrate moisture content because the $6-\mathrm{mm}$ irrigation exhibited higher moisture content compared with $3 \mathrm{~mm}$ irrigation in both study years (Fig. 3).

Green turf cover. The GTC was affected by all factors but to a different extent for each one of them. Based on the observed magnitude of the differences among the three factors, GTC was mostly influenced by substrate depth but not as much by irrigation regime and substrate type (Fig. 4; Table 2). Differences were more pronounced during the first study year (2010) compared with the second one (2011) for all treatments, presumably as a result of lower summer temperatures in 2011 compared with 2010 (Fig. 1). Manilagrass growth started to decline $6 \mathrm{~d}$ after the initiation of moisture deficit and was completely halted after $18 \mathrm{~d}$ for all treatments. Limited growth and lack of turfgrass species survival have been observed in studies where restricted substrate depth was combined with extreme drought conditions. Using digital image analysis, Steinke et al. (2011) compared growth response of various bermudagrass and buffalograss cultivars under restricted $(10 \mathrm{~cm})$ and unrestricted soil depth during consecutive $60-\mathrm{d}$ drought. They reported that in $10-\mathrm{cm}$ depth, no grass survived and the sward was completely browned off within the first $20 \mathrm{~d}$ of drought imposition, whereas all entries survived when planted on unrestricted soil depth and subjected to the same drought level.

GTC exhibited minimal differences between the two substrate types during the first study year (Fig. 4). In that case, GTC was slightly greater in the locally formulated substrate compared with the crushed tiles. This could be attributed to the higher water content of locally formulated substrate compared with the crushed tiles one according to Figures $2 \mathrm{~B}$ and 3. Taking into consideration that fertilization was not applied during moisture deficit periods, the increased nutrient status of the crushed tiles substrate (Table 1) was expected to increase shoot and leaf production. Such lush growth has been documented to negatively affect the drought tolerance of turfgrasses as well as of other plant species. Ebdon et al. (1999) found increased evapotranspiration as shoot growth increased after nitrogen fertilization in Poa pratensis, whereas Nagase and Dunnett (2011) reported that plant drought 

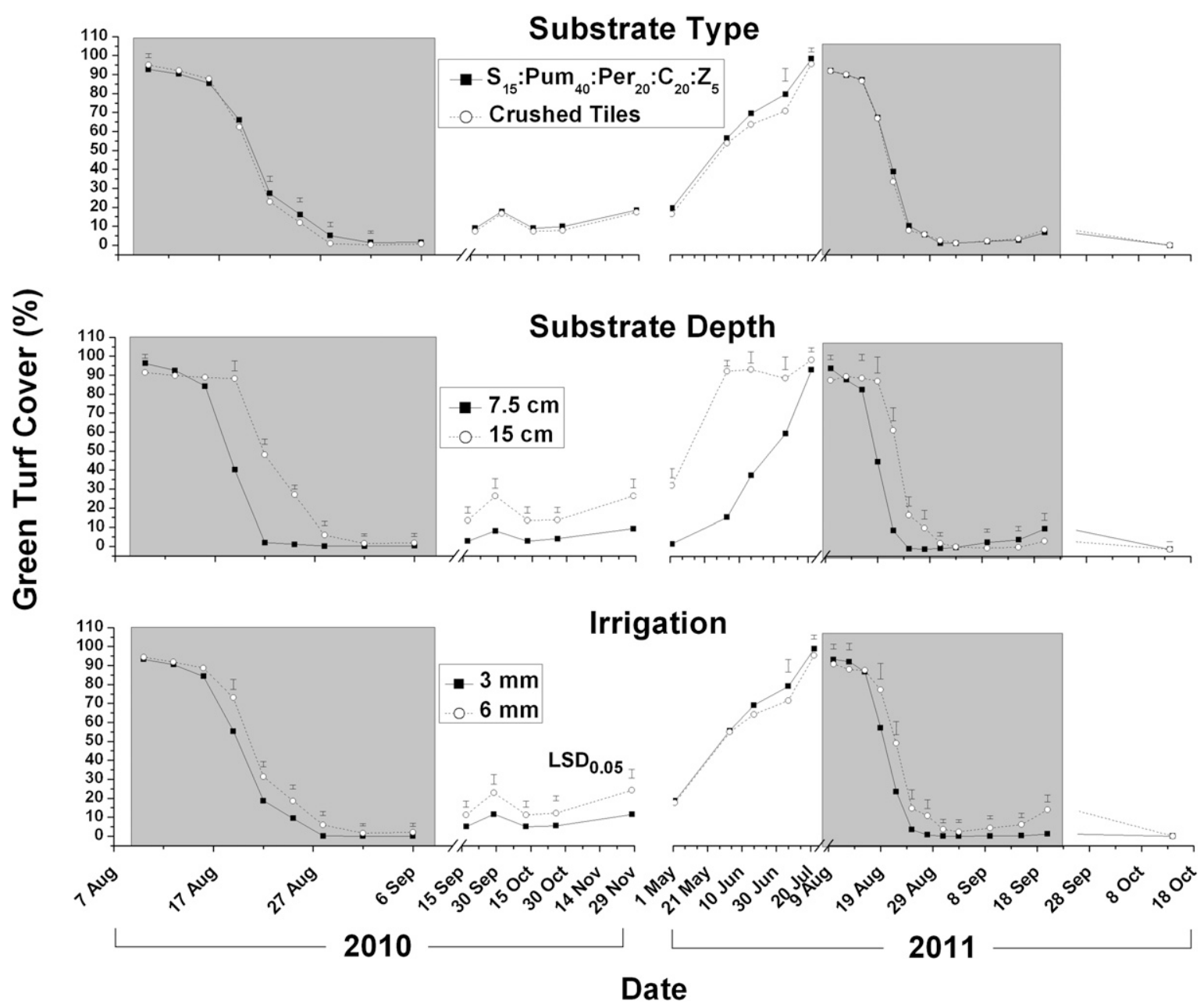

Fig. 4. Green turf cover $(\%)$ as affected by substrate type $\left(\mathrm{S}_{15}: \mathrm{Pum}_{40}: \mathrm{Per}_{20}: \mathrm{C}_{20}: \mathrm{Z}_{5}\right.$, where $\mathrm{S}=$ sandy loam soil; $\mathrm{Pum}=$ pumice; $\mathrm{Per}=$ perlite; $\mathrm{C}=$ compost; and $\mathrm{Z}=$ zeolite in volumetric proportions that are indicated by their subscripts and commercial based on crushed tiles), depth $(7.5 \mathrm{~cm}$ or $15 \mathrm{~cm})$, and irrigation regime $(3 \mathrm{~mm}$ or $6 \mathrm{~mm}$ ). Values are the mean of five replications. Bars represents Fisher' least significance difference (LSD) at $P<0.05$. The gray areas correspond to the moisture deficit period of each study year (2010 and 2011).

tolerance was reduced as the organic amendment of the substrate increased as a result of the promotion of lush foliage growth.

Substrate depth provided the most pronounced differences in both study years because the deeper substrates improved GTC for the whole duration of the study (Fig. 4). GTC improvement in the deeper profiles was attributed to their increased water content compared with the shallow ones (Fig. 3). It was also expected that deeper substrates would have produced more roots, thus exploiting water from deeper layers of the $15-\mathrm{cm}$ profile as compared with 7.5-cm substrate depth and, therefore, better withstood drought stress (Huang et al., 1997; Marcum et al., 1995) and, concomitantly, produced higher GTC (Karcher et al., 2008).

A high irrigation regime $(6 \mathrm{~mm})$ provided better GTC measurements compared with the lower regime of $3 \mathrm{~mm}$. Differences between irrigation regimes followed those observed at substrates' moisture content measurements (Figs. 3 and 4). Similar results were reported by $\mathrm{Fu}$ et al. (2004) for $Z$. japonica visual quality ratings. The researchers observed a quick decline in visual quality ratings $20 \mathrm{~d}$ after water stress imposition, when irrigation was applied at $20 \%, 40 \%$, and $60 \%$ of actual evapotranspiration. The $20 \%$ irrigation resulted in the most severe visual quality reduction followed by $40 \%$ irrigation. In our case, GTC reduction occurred within $10 \mathrm{~d}$ after the initiation of moisture deficit treatments, but this difference could be attributed either to reduced substrate depth compared with $\mathrm{Fu}$ et al. (2004) or to a different response of $Z$. japonica and $Z$. matrella to water stress as reported by White et al. (2001).

Normalized difference vegetation index. As an overall indicator of Manilagrass condition, NDVI further supported the findings of previous measurements (Fig. 5). Substrate type provided significant differences only during the first moisture deficit period (2010) when locally produced substrate exhibited increased NDVI values compared with the crushed tiles substrate.

In contrast to substrate type, substrate depth provided the most pronounced differences as in the case of GTC (Table 2). Although NDVI values were similar at the initiation of each moisture deficit period, the deeper substrate $(15 \mathrm{~cm})$ exhibited larger NDVI values compared with the shallow depth of $7.5 \mathrm{~cm}$ during both study years (Fig. 5).
The beneficial effects of deeper profiles could be attributed to several factors. First, deeper substrates contribute to increased water moisture content as a result of their capacity to contain larger amounts of water (Fig. 3). Second, deeper substrates have been found to ameliorate temperature extremes (Boivin et al., 2001). This effect is expected to improve further in highly porous media such as those used for green roofing as a result of the insulating performance of the air entrapped in the substrate porosity (Kotsiris et al., 2012a). Third, increasing the substrate depth might have a direct impact on the inherited drought tolerance mechanism of each species. Huang (1999) pointed out that the drought tolerance mechanism of $B$. dactyloides and to a lesser extent of $Z$. japonica is stress avoidance by reducing surface roots and redistributing the root system into deeper depths to exploit deeper water reservoirs. However, on green roof systems, shallow substrate profiles prohibit the expression of this drought avoidance mechanism and thus render the plants to increased stress. By increasing the substrate depth, the avoidance mechanism could be partially used and might contribute to the increased NDVI measurements. 

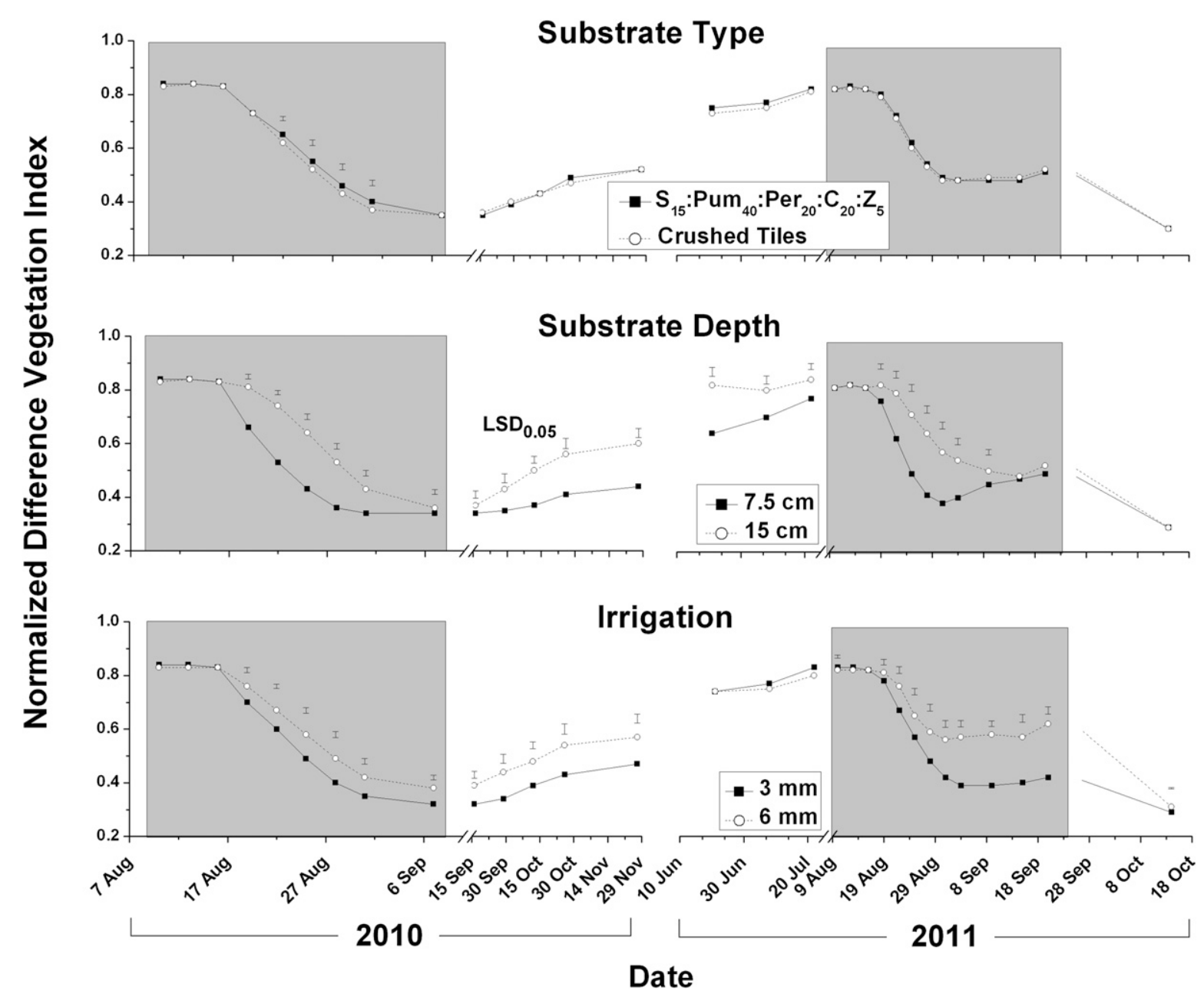

Fig. 5. Normalized difference vegetation index as affected by substrate type $\left(\mathrm{S}_{15}: \operatorname{Pum}_{40}: \operatorname{Per}_{20}: \mathrm{C}_{20}: Z_{5}\right.$, where $\mathrm{S}=$ sandy loam soil; Pum = pumice; Per = perlite; $\mathrm{C}=$ compost; and $\mathrm{Z}=$ zeolite in volumetric proportions that are indicated by their subscripts and commercial based on crushed tiles), substrate depth ( $7.5 \mathrm{~cm}$ or 15 $\mathrm{cm}$ ), and irrigation regime ( $3 \mathrm{~mm}$ or $6 \mathrm{~mm}$ ). Values are the mean of five replications. Bars represents Fisher' least significance difference (LSD) at $P<0.05$. The gray areas correspond to the moisture deficit period of each study year (2010 and 2011).

The higher irrigation regime resulted in greater NDVI values in comparison with the low irrigation regime for both study years. Differences were not as pronounced as for substrate depth during the first study year (2010). However, during the drought period of the second study year (2011), differences increased substantially (Fig. 5). The increased differences between the two irrigation regimes were contributed to the lower temperature extremes that occurred in 2011 compared with 2010 that permitted better growth of turfgrass sward receiving the high irrigation regime.

Leaf relative water content. RWC is a measurement that indicates the physiological status of the plant through the determination of cellular water deficit. A high RWC is indicative of a plant with a higher turgidity and, thus, a better physiological status. The RWC was similar between the two substrates for both study years further substantiating previous GTC and NDVI observations that determined a similar behavior of the two substrates (Fig. 6).

In contrast, RWC was greater when plants were grown in the deeper substrates and under the 6-mm irrigation regime. CarmoSilva et al. (2009) reported that $Z$. japonica
RWC started to decrease only after substrate water content decreased below 10\%. Similarly, in our study, RWC decreased abruptly when substrate moisture content was $10 \%$ to $15 \% \mathrm{v} / \mathrm{v}$ depending on the treatment (Figs. 3 and 6). Fu et al. (2004) determined that water stress imposition on Z. japonica 'Meyer' initiated RWC reduction after $\approx 20 \mathrm{~d}$. They reported that RWC reduction was severe (less than 50\% RWC) after $55 \mathrm{~d}$ when the applied irrigation was $20 \%$ of the actual evapotranspiration, whereas the $40 \%$ irrigation always remained above $60 \%$ RWC. In our case, RWC reached $50 \%$ for both irrigation regimes $(40 \%$ and $20 \%$ of actual evapotranspiration) after only 9 to $12 \mathrm{~d}$ from the initiation of moisture deficit cycle depending on the treatment (Fig. 6). The significantly reduced time for RWC to reach $50 \%$ reduction in our study was attributed to the limited green roof substrate depth compared with the unrestricted one of Fu et al. (2004).

Recovery. After the moisture deficit imposition, Manilagrass recovery potential was able to be assessed only in 2010 because in year 2011, natural precipitation was minimal in September and occurred mostly in October. Thus, Manilagrass did not have the necessary time to recover before its induction to winter dormancy.

In 2010, the moisture deficit period ended in September coinciding with the first fall rainfalls and it was able to recover from all treatments as indicated by GTC (Fig. 4) and NDVI (Fig. 5). Because irrigation was not provided, recovery speed depended only on natural fall rainfall and thus Manilagrass GTC did not reach the pre-deficit levels and fluctuated in accordance with natural precipitation (Figs. 1 and 4). Two weeks after the occurrence of precipitation events, Manilagrass recovery reached $20 \%$ to $25 \%$ GTC, which coincides with the percent recovery $(22 \%)$ reported by Qian and Fry (1997) for Z. japonica 2 weeks after the termination of water deficit treatments.

During fall recovery in 2010, differences observed during the moisture deficit period continued to exist indicating a carry on effect on Manilagrass GTC and NDVI. The positive impact of deeper substrate depth and higher irrigation was evident, whereas differences between substrate types were eliminated.

In the recovery period of 2011 , a single measurement was performed because turfgrass growth and quality, as indicated by 


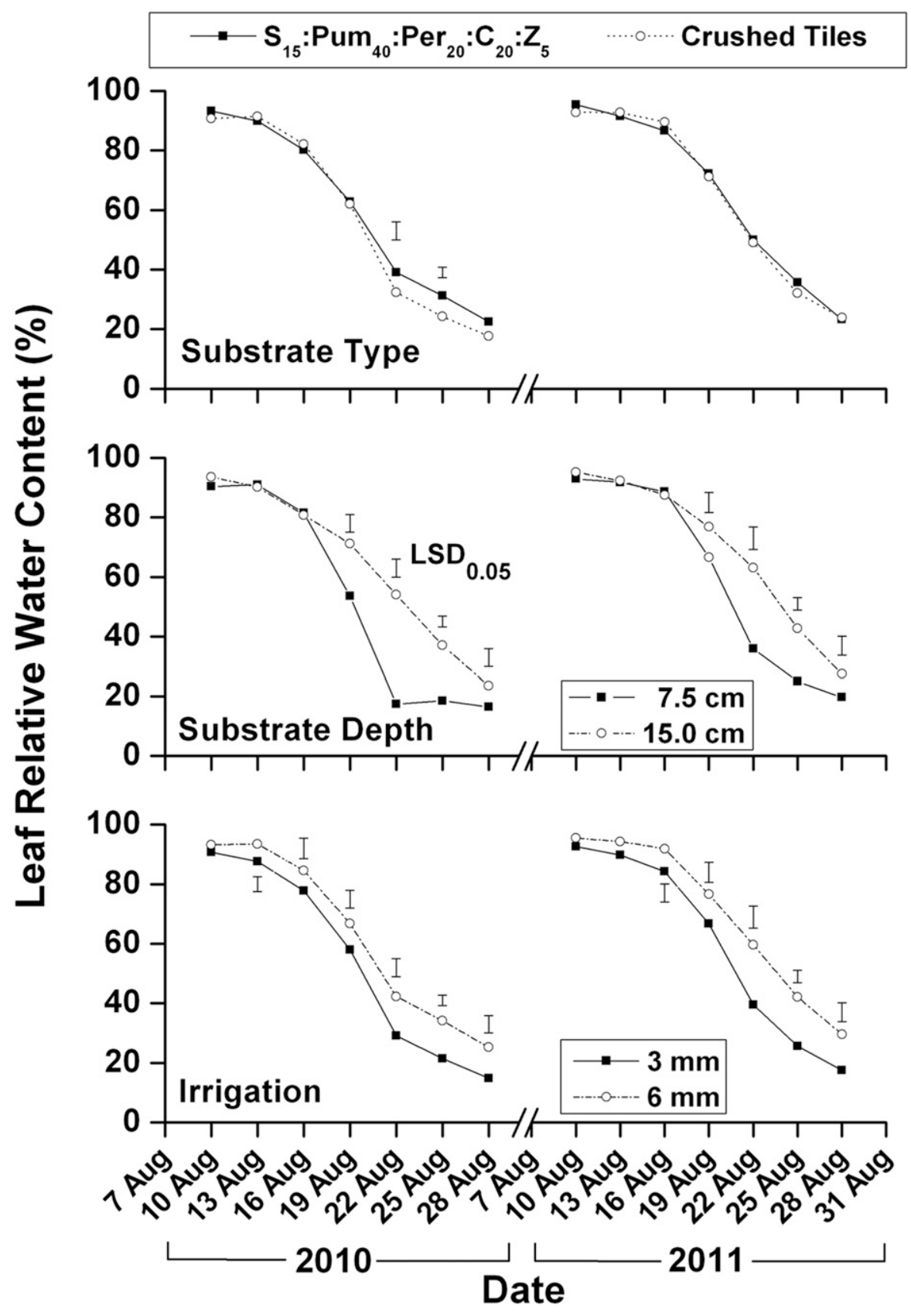

Fig. 6. Leaf relative water content (\%), as affected by substrate type $\left(\mathrm{S}_{15}: \mathrm{Pum}_{40}: \operatorname{Per}_{20}: \mathrm{C}_{20}: \mathrm{Z}_{5}\right.$, where $\mathrm{S}=$ sandy loam soil; Pum = pumice; Per = perlite; $\mathrm{C}=$ compost; and $\mathrm{Z}=$ zeolite in volumetric proportions that are indicated by their subscripts and commercial based on crushed tiles), substrate depth $(7.5 \mathrm{~cm}$ or $15 \mathrm{~cm})$, and irrigation regime (3 $\mathrm{mm}$ or $6 \mathrm{~mm}$ ) during the moisture deficit periods. Values are the mean of five replications. Bars represents Fisher' least significance difference (LSD) at $P<0.05$.

GTC and NDVI measurements, remained stagnant as a result of the limited September rainfall events (only $3.4 \mathrm{~mm}$ of precipitation, on 20 Sept. 2011; Fig. 1). In 2011, rainfalls occurred mostly in October and thus, Manilagrass entered its winter dormancy before its recovery from water deficit treatments.

After the end of winter dormancy in Spring 2011, Manilagrass was irrigated to reach a similar level of GTC that was necessary to initiate the second moisture deficit period. In the spring period after dormancy, only deeper substrates improved Manilagrass GTC (Fig. 4) and NDVI (Fig. 5) compared with shallow improved drought tolerance of Manilagrass compared with the shallow one. However, because load is a crucial issue on green roof construction, if substrate depth must be reduced to $7.5 \mathrm{~cm}$, then irrigation should exceed $6 \mathrm{~mm}$ every $3 \mathrm{~d}$ to have adequate growth and successfully overcome summer moisture deficit periods.

\section{Literature Cited}

Anderson, W.F., M.E. Snook, and A.W. Johnson. 2007. Flavonoids of zoysiagrass (Zoysia spp.) cultivars varying in fall armyworm (Spodoptera frugiperda) resistance. J. Agr. Food Chem. 55:1853-1861.

ASTM D 2974-07a. 2007. Standard test methods for moisture, ash, and organic matter of peat and other organic soils. American Society for Testing and Materials, West Conshohocken, PA.

Beard, J.B. and R.L. Green. 1994. The role of turfgrasses in environmental protection and their benefits to humans. J. Environ. Qual. 23:452-460.

Beattie, D.J. and R.D. Berghage. 2004. Green roof media characteristics: The basic, p. 411-416. Proc. of 2nd North American Green Roof Conference: Greening Rooftops for Sustainable Communities Conference, Portland, OR, 2-4 June 2004. The Cardinal Group, Toronto, Ontario, Canada.

Benvenuti, S. and D. Bacci. 2010. Initial agronomic performances of Mediterranean xerophytes in simulated dry green roofs. Urban Ecosyst. 13:349-363.

Boivin, M., M. Lamy, A. Gosselin, and B. Dansereau. 2001. Effect of artificial substrate depth on freezing injury of six herbaceous perennials grown in a green roof system. HortTechnology 11:409-412.

Bousselot, J.M., J.E. Klett, and R.D. Koski. 2010. Extensive green roof species evaluations using digital image analysis. HortScience 45:12881292.

Bousselot, J.M., J.E. Klett, and R.D. Koski. 2011. Moisture content of extensive green roof substrate and growth response of fifteen temperate plant species during dry down. HortScience 46:518-522.

Carmo-Silva, A.E., A. Francisco, S.J. Powers, A.J. Keys, L. Ascensão, M.A.J. Parry, and M.C. Arrabaça. 2009. Grasses of different $\mathrm{C}_{4}$ subtypes reveal leaf traits related to drought tolerance in their natural habitats: Changes in structure, water potential and amino acid content. Amer. J. Bot. 96:1222-1235.

Claus, K. and S. Rousseau. 2012. Public versus private incentives to invest in green roofs: A cost benefit analysis for Flanders. Urban For. Urban Green. 11:417-425.

De Luca, A., M. Volterrani, M. Gaetani, N. Grossi, P. Croce, M. Mocioni, F. Lulli, and S. Magni. 2008a. Warm-season turfgrass adaptation in northern Italy. Proc. of the 1st ETS Conf., 19-20 May 2008, Pisa, Italy. p. 75-76.

profiles. In contrast, substrate types and irrigation regime were similar except from a single date when high irrigation and substrate formulated by locally available materials had greater GTC (Fig. 4).

\section{Conclusions}

Substrate depth was the most significant factor that improved growth and drought resistance of Z. matrella 'Zeon', further confirming that substrate depth is among the most important factors on extensive green roof systems. The deeper substrate resulted in
De Luca, A., M. Volterrani, M. Gaetani, N. Grossi, P. Croce, M. Mocioni, and F. Lulli. 2008b. Warm season turfgrass adaptation in Europe north of the $45^{\circ}$ parallel, p. 496-501. In: Crews, D. and R. Lutz (eds.). Science and golf V. Energy in Motion, Inc., Mesa, AZ.

Dunnett, N., A. Nagase, and A. Hallam. 2008. The dynamics of planted and colonising species on a green roof over six growing seasons 20012006: Influence of substrate depth. Urban Ecosyst. 11:373-384. substrate depth and supplementary watering on the growth of nine herbaceous perennials in a
Dunnett, N. and A. Nolan. 2004. The effect of 
semi-extensive green roof. Acta Hort. 643: 305-309.

Durhman, A.K., D.B. Rowe, and C.L. Rugh. 2006. Effect of watering regimen on chlorophyll fluorescence and growth of selected green roof plant taxa. HortScience 41:1623-1628.

Durhman, A.K., D.B. Rowe, and C.L. Rugh. 2007. Effect of substrate depth on initial growth, coverage, and survival of 25 succulent green roof plant taxa. HortScience 42:588-595.

Ebdon, J.S., A.M. Petrovic, and R.A. White. 1999. Interaction of nitrogen, phosphorus, and potassium on evapotranspiration rate and growth of kentucky bluegrass. Crop Sci. 39:209 218.

FLL-Forschungsgesellschaft Landschaftsentwicklung Landschaftsbau e.V. 2008. Richtlinien für die Planung, Ausführung und Pflege von Dachbegrünungen. Richtlinien für Dachbegrünungen (Guideline for the planning, execution and upkeep of green-roof sites). Bonn, Germany.

Fu, J., J. Fry, and B. Huang. 2004. Minimum water requirements of four turfgrasses in the transition zone. HortScience 39:1740-1744.

Getter, K.L. and D.B. Rowe. 2006. The role of extensive green roofs in sustainable development. HortScience 41:1276-1285.

Getter, K.L. and D.B. Rowe. 2008. Media depth influences Sedum green roof establishment. Urban Ecosyst. 11:361-372.

Huang, B. 1999. Water relations and root activities of Buchloe dactyloides and Zoysia japonica in response to localized soil drying. Plant Soil 208:179-186.

Huang, B., R.R. Duncan, and R.N. Carrow. 1997. Drought-resistance mechanisms of seven warmseason turfgrasses under surface soil drying: II. Root aspects. Crop Sci. 37:1863-1869.

Karcher, D.E. and M.D. Richardson. 2005. Batch analysis of digital images to evaluate turfgrass characteristics. Crop Sci. 45:1536-1539.

Karcher, D.E., M.D. Richardson, K. Hignight, and D. Rush. 2008. Drought tolerance of tall fescue populations selected for high root/shoot ratios and summer survival. Crop Sci. 48:771-777.

Kargas, G., N. Ntoulas, and P.A. Nektarios. 2013. Moisture content measurements of green roof substrates using two dielectric sensors. HortTechnology 23:177-186.

Kotsiris, G., A. Androutsopoulos, E. Polychroni, and P.A. Nektarios. 2012a. Dynamic U-value estimation and energy simulation for green roofs. Energy Build. 45:240-249.

Kotsiris, G., P.A. Nektarios, and A.T. Paraskevopoulou. 2012b. Lavandula angustifolia growth and physiology is affected by substrate type and depth when grown under Mediterranean semiintensive green roof conditions. HortScience 47:311-317.

Latocha, P. and A. Batorska. 2007. The influence of irrigation system on growth rate and frost resistance of chosen ground cover plants on extensive green roofs. Ann. Warsaw Univ. of Life Sc.SGGW, Hort. and Landscape Architecture 28: 131-137.

MacIvor, J.S. and J. Lundholm. 2011. Performance evaluation of native plants suited to extensive green roof conditions in a maritime climate. Ecol. Eng. 37:407-417.

Marcum, K.B., M.C. Engelke, S.J. Morton, and R.H. White. 1995. Rooting characteristics and associated drought resistance of zoysiagrasses. Agron. J. 87:534-538.

Monterusso, M.A., D.B. Rowe, and C.L. Rugh. 2005. Establishment and persistence of Sedum spp. and native taxa for green roof applications. HortScience 40:391-396.

Morris, K. 2001. National zoysiagrass test 1996. National Turfgrass Evaluation Program. Final Report 1997-2000, NTEP No. 01-15.

Nagase, A. and N. Dunnett. 2010. Drought tolerance in different vegetation types for extensive green roofs: Effects of watering and diversity. Landsc. Urban Plan. 97:318-327.

Nagase, A. and N. Dunnett. 2011. The relationship between percentage of organic matter in substrate and plant growth in extensive green roofs. Landsc. Urban Plan. 103:230-236.

Nektarios, P.A., I. Amountzias, I. Kokkinou, and N. Ntoulas. 2011a. Green roof substrate type and depth affect the growth of the native species Dianthus fruticosus under reduced irrigation regimens. HortScience 46:1208-1216.

Nektarios, P.A., S. Kastritsis, N. Ntoulas, and P. Tsiotsiopoulou. 2011b. Substrate amendment effects on potted plant production and dry weight partition of Lantana camara. HortScience 46:864-869.

Ntoulas, N., P.A. Nektarios, K. Spaneas, and N. Kadoglou. 2012. Semi-extensive green roof substrate type and depth effects on Zoysia matrella 'Zeon' growth and drought tolerance under different irrigation regimens. Acta Agriculturae Scandinavica, Section B-Plant. Soil Sci. 62:165-173.

Olmstead, M.A., R. Wample, S. Greene, and J. Tarara. 2004. Nondestructive measurements of vegetative cover using digital image analysis. HortScience 39:55-59.

Patton, A.J. 2010. Selecting zoysiagrasses: Pest tolerance and other criteria. Golf Course Mgt. $78: 80-85$.
Patton, A.J. and Z.J. Reicher. 2007. Zoysiagrass species and genotypes differ in their winter injury and freeze tolerance. Crop Sci. 47:16191627.

Qian, Y.L. and J.D. Fry. 1997. Water relations and drought tolerance of four turfgrasses. J. Amer. Soc. Hort. Sci. 122:129-133.

Qian, Y.L. and M.C. Engelke. 1997. Evaluation of zoysiagrass genotypes for shade tolerance. Texas Turfgrass Res. J. TURF-97:1-11.

Richardson, M.D., D.E. Karcher, and L.C. Purcell. 2001. Quantifying turfgrass cover using digital image analysis. Crop Sci. 41:1884-1888.

Rowe, D.B., M.A. Monterusso, and C.L. Rugh. 2006. Assessment of heat-expanded slate and fertility requirements in green roof substrates. HortTechnology 16:471-477.

Spronken-Smith, R.A. and T.R. Oke. 1998. The thermal regime of urban parks in two cities with different summer climates. Intl. J. Remote Sens. 19:2085-2104.

Steinke, K., D. Chalmers, J. Thomas, and R. White. 2011. Bermudagrass and buffalograss drought response and recovery at two soil depths. Crop Sci. 51:1215-1223.

Takebayashi, H. and M. Moriyama. 2009. Study on the urban heat island mitigation effect achieved by converting to grass-covered parking. Sol. Energy 83:1211-1223.

Thuring, C.E., R.D. Berghage, and D.J. Beattie. 2010. Green roof plant responses to different substrate types and depths under various drought conditions. Hort Technology 20:395-401.

Turner, N.C. 1981. Techniques and experimental approaches for the measurement of plant water status. Plant Soil 58:339-366.

VanWoert, N.D., D.B. Rowe, J.A. Andresen, C.L. Rugh, and L. Xiao. 2005. Watering regime and green roof substrate design affect Sedum plant growth. HortScience 40:659-664.

Volterrani, M., N. Grossi, F. Lulli, and M. Gaetani. 2008. Establishment of warm-season turfgrass species by transplant of single potted plants. Acta Hort. 783:77-84.

White, R.H., M.C. Engelke, S.J. Anderson, B.A. Ruemmele, K.B. Marcum, and G.R. Taylor. 2001. Zoysiagrass water relations. Crop Sci. 41:133-138.

Williams, N.S.G., J.P. Rayner, and K.J. Raynor. 2010. Green roofs for a wide brown land: Opportunities and barriers for rooftop greening in Australia. Urban For. Urban Green. 9:245-251.

Wolf, D. and J.T. Lundholm. 2008. Water uptake in green roof microcosms: Effects of plant species and water availability. Ecol. Eng. 33:179-186. 